\title{
Semi-Endogenous Growth Model for Developing Countries: A Modification to Jones Model
}

\author{
Hari Nugroho' ${ }^{1}$ N. Haidy Ahmad Pasay ${ }^{2}$, Arie Damayanti ${ }^{3}$, \\ Maddaremmeng A. Panennungi ${ }^{4}$
}

\begin{abstract}
Semi-endogenous growth model emphasizes human capital accumulation and technological advances in supporting economic growth. While most countries in the world lack the ability to accumulate their human capital and advance in technology, the privilege of research and development lies on part of developed nations. The increase in the stock of knowledge can come from different interactions with other countries in the world. But the crucial point to make is what underlies these differences among nations in the world. This study modifies Jones Model by embedding characteristics that different countries in the world. Such an attempt is directed to produce a more general model of semi-endogenous growth to be applicable to all countries in the world. The end result of this study is to present a more general model that will be easily applicable to different countries in the world.
\end{abstract}

Keywords: Semi-endogenous, human capital, technological progress, stock of knowledge, economic growth

\begin{abstract}
Abstrak
Model pertumbuhan semi-endogen menekankan perkembangan teknologi dan akumulasi human capital dalam mendorong pertumbuhan ekonomi. Kemampuan untuk melakukan riset dan pengembangan hanya dimiliki oleh beberapa negara maju, sedangkan sebagian besar negara lainnya masih mengalami hambatan dalam hal perkembangan teknologi dan akumulasi human capital. Pertumbuhan dalam stok ilmu pengetahuan dapat terjadi karena interaksi-interaksi antara negara-negara tersebut dengan negara-negara lain di dunia. Penyebab-penyebab ini juga akan menjadi fokus dari penelitian ini. Penelitian ini akan memodifikasi model Jones dengan memasukkan karakteristik-karakteristik yang membedakan masingmasing negara di dunia. Usaha tersebut akan menghasilkan sebuah model semi endogen yang bersifat lebih umum sehingga dapat diaplikasikan pada seluruh negara di dunia. Hasil akhir dari penelitian ini adalah sebuah model umum yang bisa digunakan untuk menganalisa negara-negara di dunia dengan perbedaanperbedaan yang ada.
\end{abstract}

Kata Kunci: semi endogen, modal manusia, perkembangan teknologi, stok ilmu pengetahuan, pertumbuhan ekonomi

How to Cite:

Nugroho, H., Pasay, N. H. A., Damayanti, A., \& Panennungi, M. A. (2019). Semi-Endogenous Growth Model for Developing Countries: A Modification to Jones Model Signifikan: Jurnal IImu Ekonomi. Vol. 8(1): 121 134. doi: http://dx.doi.org/10.15408/sjie.v8i1.9136. 


\section{Introduction}

A hallmark of endogenous growth literature is that human capital and technological progress play critical roles in affecting economic growth. This paper argues that a semiendogenous growth model developed by Jones (2002) does not accommodate crosscountry characteristics hence a modification is required in order to be applicable to countries in the world. Semi-endogenous growth model was established mainly in developed countries with different characteristics to those of developing ones. The applicability of semi-endogenous growth model is then in question. Powerful prediction of the model along with its ability to match with empirical data is the ultimate goal in building an economic model.

In a semi-endogenous growth model, technological progress is the main engine of growth where sustainability of economic growth is determined by technological innovation and stock of knowledge. Achievements in industrial and academic research play an important role in accomplishing technological innovation and progress in knowledge. Availability and a certain level of human capital thus guarantee those achievements. Romer (1986) mentioned that technological progress is a subsequent product of continuous efforts in research and development with current human capital and stock of knowledge. Jones (1995b) states that the R-D based models of endogenous growth are rejected by the criterion. Semi-endogenous growth model has put a strong emphasis on human capital and technological progress as the main determinants of economic growth.

Less-developed countries depend on knowledge and technology created in the developed world in order to accumulate their stock of knowledge. The quantity and the quality of R\&D workers in developing countries are low or much worse non-existent due to no $R \& D$ or no available workers. This problem of $R \& D$ workers can root from the quality of education. Low quality of education hence low quality of human capital is a problem every developing country needs to resolve. Lucas Jr (1988) and Stokey (1988) have found the correlation between education and productivity of workers. Lucas Jr (1988) and Stokey (1988) claim education will subsequently generate positive externalities. Thus it is obvious that the productivity of workers in developing nations is much lower than that of developed nations.

Coe \& Helpman (1995) found that, of all OECD countries, only 7 countries that put $90 \%$ of the fund in R\&D in 1991. Coe \& Helpman (1995) claim that of $96 \%$ of research industrial countries provided a fund in the world in 1990 . The ability to innovate is the only a privilege to certain countries. To those countries less fortunate in terms of ability to innovate then being able to absorb new knowledge and technology from developed countries through the various channel such as international trade, foreign direct investment, and so on would be the only hope. Knowledge and technology must be created somewhere and spill everywhere. Therefore to assume a model that represent identical characteristics of countries being analyzed would undermine the result produced. Coe et al. (2008) show that domestic and foreign R \& D capital stocks have measurable impacts on TFP.

Even so, less-developed countries cannot absorb knowledge from developed countries 
easily and fully. There are barriers and obstacles that keep less-developed countries from making full use of advances in knowledge and technology from industrial countries. Such barriers and obstacles thus differentiate these countries from the developed ones. Barriers may include such things as the quality of institutions, wars, health levels, geographical conditions, the availability of natural resources, and so on. In a broader perspective, Acemoglu et al. (2005) then concluded that the difference in the rate of economic growth between countries is not merely the issue of capital accumulation, the role of technology and human capital, there is the role of institutions in it. Acemoglu et al., (2001) even suggest that in certain cases, institutions are the main determinants of economic growth.

Bringing these barriers and obstacles to attention and concentrate to eliminate these problems would be the key to increasing growth rates. It is then important to acknowledge these problems in the semi-endogenous growth model. By accommodating the obstacles in modeling economic growth would give a better understanding of the problem at hand and also enhance the prediction power of the model.

A modification to Jones Model is necessary if we would like to apply the model to analyze economic growth in developing countries, specifically in Indonesia. Modification to the model must accommodate problems and obstacles as mentioned above. Modification becomes inevitable because different characteristics between developing countries and developed ones do exist. In addition, the majority of growth models are built by taking samples in developed countries so that the assumptions and characteristics of the model cannot describe the situation in the developing countries well. Therefore a discussion of the growth model with regard to the characteristics of developing countries and its constraints will be able to provide a broader understanding of the growth model itself. This research is also expected to provide new treasures for the field of macroeconomics.

\section{Methods}

To apply Jones Model to developing countries, we have to modify by including the variables that characterize developing countries. The initial setting of Jones Model consists of 8 basic equations so then the choice of equations to be modified becomes crucial at the very beginning. If we look again at the conclusion of Jones (2002), which states that the engine of growth is ideas creation. Then, we can confidently state that the equation to be modified relates to ideas creation. The problems faced in developing countries and the difference between developing and developed countries are the low levels of knowledge and technology accumulation. As mentioned above, this problem can be summarized into one major dimension that is an institutional problem. Institutions have a broad meaning and include such things as potential tribal, religious, racial and inter-group tensions, bureaucratic quality, government stability, corruption, law and order stewardship, level of trade openness, military presence on the political stage, investment profile, potential conflict internal and external, and maturity levels of democracy.

Our study is different from Hall \& Jones (1999) in terms of how institutional factors affect growth rates. According to Hall \& Jones (1999), the economy of a country is influenced 
by the factors that make up the social infrastructure, . Per capita growth rates are influenced by in the following relationship:

$$
\log \frac{Y}{L}=\alpha+\beta . S+\epsilon
$$

and

$$
S=\gamma+\delta \log \frac{Y}{L}+X \theta+\eta
$$

From the above equation, we can quickly conclude that $S$ directly affects $\frac{Y}{L}$. While that is not the case in our study. We argue that $S$ will affect the amount of new knowledge and technology absorbed by less-developed countries. Since the quality of institutions are lower than those of counterparts in the developed world than we could expect that the amount of new knowledge and technology is not fully absorbed. So $S$ will influence $\frac{Y}{L}$ indirectly through the growth of $A_{t}$. Formally the setting of Jones (2002) looks like this:

$$
\begin{aligned}
& Y_{t}=A_{t}^{\sigma} \cdot K_{t}^{\alpha} \cdot H_{Y_{t}}^{1-\alpha} \\
& \dot{K}_{t}=s_{K_{t}} \cdot Y_{t}-d \cdot K_{t}, K_{0}>0 \\
& H_{Y_{t}}=h_{t} \cdot L_{Y_{t}} \\
& h_{t}=e^{\psi \cdot l_{h t}} \\
& \dot{A}_{t}=\delta \cdot H_{A_{t}}^{\lambda} \cdot A_{t}^{\phi}, A_{0}>0 \\
& H_{A_{t}}=\sum_{i=1}^{M} h_{i t}^{\theta} \cdot L_{A_{i t}} \\
& N_{t}=N_{0} \cdot e^{n t} \\
& L_{A_{t}}+L_{Y_{t}}=L_{t}=\left(1-l_{h t}\right) \cdot N_{t}
\end{aligned}
$$

We modify equation (5) because it states that the growth of the stock of knowledge is a function influenced by aggregate human capital working in the R\&D and a stock of knowledge in developed countries. Equation (5) is an equation describing the growth of the stock of knowledge. Remember, Jones (2002) is semi-endogenous growth model that defines growth in output as driven by the growth in knowledge. Equation (5) is the core of Jones Model. It is this equation that builds the essence of the entire model. Therefore the choice to modify equation (5) is justified on solid ground. We will derive equations in the same manner Jones (2002) did to his model.

The stock of knowledge in developed countries is higher than the stock of knowledge in developing countries. The stock of knowledge in developing countries is constrained by the various problems encapsulated within the institution. In addition, developing countries depend on the stock of knowledge of developed countries.

The growth of the stock of knowledge in developing countries is strongly influenced by the growth of the stock of knowledge in developed countries so that we can express this relationship as $A_{t}^{*}$, the stock of knowledge in developed countries and $A_{t}$ is stock of knowledge in developing countries. Then it follows that $A_{t}^{*}>A_{t}$. In other words, the stock of knowledge 
in developed countries is higher than the stock of knowledge in developing countries. There is a gap in knowledge and technology hence it will flow from developed countries to less developed countries. So stock of knowledge in developing countries is a function of stock of knowledge in developed countries with a limit or a barrier. We can write the above argument as $\frac{A_{t}^{*}}{A_{t}}$. This ratio reflects a knowledge spillover from developed countries to developing

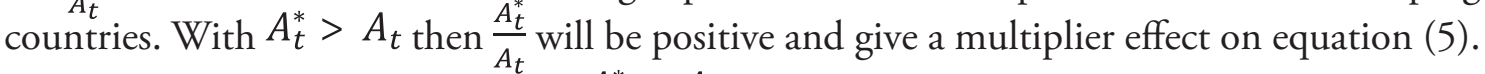
If there is a situation in time, where $A_{t}^{*}=A_{t}$, then we can conclude that stock of knowledge in developed countries has equal stock of knowledge in developing countries. In other words, we can say that developing countries have become developed countries.

As mentioned earlier, the problems that arise in developing countries and often influence their economic growth is a complex problem in the so-called institutional dimension. This institutional factor can decelerate or accelerate the process of ideas creation depending on the size of the index number. Developing countries are hypothesized to have much lower institutional factors than institutional factors in developed countries. This prevents knowledge spillover from developed countries to be utilized or absorbed to the fullest. If we symbolize the constraints of this institutional factor as $1-S$, where $S$ is an institutional index number $0<S \leq 1$, then the ratio that states knowledge spillover in the preceding paragraph would be $\left(\frac{A_{t}^{*}}{A_{t}}\right)^{1}$

In developed countries, $S \approx 1$ whereas, with the presence of inhibiting factors as described by Acemoglu et al., (2005) and Hall \& Jones (1999), in developing countries $S$ $<1$. The impact of economic growth through the growth of $A_{t}$ in the case of developing countries will not be large enough because the benefit from $\frac{A_{t}^{*}}{A_{t}}$ will not be fully realized and developing countries can only benefit $\left(\frac{A_{t}^{*}}{A_{t}}\right)^{1-S} . S$ is an inhibiting factor or institution in Acemoglu et al., (2005) or social infrastructure in Hall \& Jones (1999). $S$ has a theoretical maximum and minimum value of 1 and 0 respectively.

Modified equation will become:

$$
\dot{A}_{t}=\delta \cdot H_{A_{t}}^{\lambda} \cdot\left[\left(\frac{A_{t}^{*}}{A_{t}}\right)^{1-S} \cdot A_{t}\right]^{\varnothing}
$$

Equation (9) states that the growth of stock of knowledge of a particular country depends on (i) the human capital working in research $\left(H_{A_{t}}\right)$; (ii) the stock of knowledge in developed countries $\left(A_{t}^{*}\right.$ ); (iii) the stock of knowledge of $\left(A_{t}\right)$; (iv) the institutional index at play in that particular country $(S)$. In this new equation, interactions between countries in the world are explicit and expressed as $\frac{A_{t}^{*}}{A_{t}}$.

When it comes to the time when a country, that originally was a developing country, has grown into a developed country, then the stock of knowledge in that country will match the stock of knowledge in developed countries or $A_{t}^{*}=A_{t}$ and the institutional index in that country high enough or $S \approx 1$. This will result in the modified equation above to "return" to equation (5) in Jones Model. We can see from equation (9) that we now have full flexibility when it comes to analyzing different countries in the world. What we mean by flexibility is that we can first determine the institutional factor, $S$, and then calculate the knowledge spillover that can take place without having to worry about other assumptions. We still utilize 
the same set assumptions as it is in Jones Model. It is common practice to proxy-developed countries as OECD countries or G-7 countries.

\section{Result and Discussion}

We can then continue to derive the remaining equations in the model. The difference lies in equation (5) that is modified to equation (9). We can derive the 8 main equations above to gain an understanding of the main determinant of long-run economic growth. The next function uses equation (1) as a start. If we notice that $H_{Y_{t}}=h_{t} . L_{Y_{t}}$, so we can obtain the following:

$$
Y_{t}=A_{t}^{\sigma} \cdot K_{t}^{\alpha} \cdot\left(h_{t} \cdot L_{Y_{t}}\right)^{1-\alpha}
$$

Both sides are raised to the power of $\frac{1}{1-\alpha}$ to become:

$$
\left(Y_{t}\right)^{\frac{1}{1-\alpha}}=\left(A_{t}^{\sigma} \cdot K_{t}^{\alpha} \cdot\left(h_{t} \cdot L_{Y_{t}}\right)^{1-\alpha}\right)^{\frac{1}{1-\alpha}}
$$

and:

$$
Y_{t^{1-\alpha}}^{\frac{1}{1-\alpha}} A_{t}^{\frac{\sigma}{1-\alpha}} \cdot K_{t}^{\frac{\alpha}{1-\alpha}} \cdot h_{t} \cdot L_{Y_{t}}
$$

where:

$$
\frac{1-\alpha}{1-\alpha}+\frac{\alpha}{1-\alpha}=\frac{1}{1-\alpha}
$$

We can rewrite the above equation as:

$$
\begin{aligned}
& Y_{t}^{\frac{1-\alpha}{1-\alpha}} \cdot Y_{t^{\frac{\alpha}{1-\alpha}}}^{\frac{\alpha}{1-\alpha}} \cdot K_{t}^{\frac{\alpha}{1-\alpha}} \cdot h_{t} \cdot L_{Y_{t}} \\
& Y_{t}^{\frac{1-\alpha}{1-\alpha}}=\frac{A_{t}^{\frac{\sigma}{1-\alpha}} \cdot K_{t}^{\frac{\alpha}{1-\alpha}} \cdot h_{t} \cdot L_{Y_{t}}}{Y_{t}^{\frac{\alpha}{1-\alpha}}} \\
& Y_{t}=\frac{K_{t}^{\frac{\alpha}{1-\alpha}}}{Y_{t}^{\frac{\alpha}{1-\alpha}}} \cdot h_{t} \cdot L_{Y_{t}} \cdot A_{t}^{\frac{\sigma}{1-\alpha}} \\
& Y_{t}=\left(\frac{K_{t}}{Y_{t}}\right)^{\frac{\alpha}{1-\alpha}} \cdot h_{t} \cdot L_{Y_{t}} \cdot A_{t}^{\frac{\sigma}{1-\alpha}}
\end{aligned}
$$

If we let:

$l_{Y_{t}}=\frac{L_{Y_{t}}}{L_{t}}$ or $L_{Y_{t}}=l_{Y_{t}} \cdot L_{t}$

Then if we insert equation (10.b) to equation (10.a), we will get:

$$
\frac{Y_{t}}{L_{t}}=y_{t}=\frac{\left(\frac{K_{t}}{Y_{t}}\right)^{\frac{\alpha}{1-\alpha}} \cdot h_{t} \cdot l_{Y_{t}} \cdot L_{t} \cdot A_{t}^{\frac{\sigma}{1-\alpha}}}{L_{t}}
$$

We can then divide both sides with $L_{t}$, to get:

$$
\frac{Y_{t}}{L_{t}}=y_{t}=\frac{\left(\frac{K_{t}}{Y_{t}}\right)^{\frac{\alpha}{1-\alpha}} \cdot h_{t} \cdot l_{Y_{t}} \cdot L_{t} \cdot A_{t}^{\frac{\sigma}{1-\alpha}}}{L_{t}}
$$


The end equation will be equation (11):

$Y_{t}=\left(\frac{K_{t}}{Y_{t}}\right)^{\frac{\alpha}{1-\alpha}} \cdot h_{t} \cdot l_{Y_{t}} \cdot L_{t} \cdot A_{t}^{\frac{\sigma}{1-\alpha}}$

If we let $k=\frac{K}{L}$, then we take log of both sides, the equation will be:

$\log k=\frac{\log K}{\log L}=\log K-\log L$

We can then derive with respect to time to obtain:

$\frac{d \log k}{d t}=\frac{d \log K}{d t}-\frac{d \log L}{d t}$

$\frac{1}{k} \cdot \dot{k}=\frac{1}{K} \cdot \dot{K}-\frac{1}{L} \cdot \dot{L}$

Or:

$\frac{\dot{k}}{k}=\frac{\dot{K}}{K}-\frac{\dot{L}}{L}$

Where:

$\frac{\dot{k}}{k}=g_{k} ; \frac{\dot{L}}{L}=n ;$

$\dot{K}=s_{K} \cdot Y-d \cdot K$

Then:

$$
\begin{aligned}
g_{k} & =\frac{s_{K} \cdot Y-d \cdot K}{K}-n=\frac{s_{K} \cdot Y}{K}-\frac{d \cdot K}{K}-n=\frac{s_{K} \cdot Y}{K}-(n+d) \\
n+g_{k}+d & =\frac{s_{K} \cdot Y}{K} \\
\frac{K}{Y} & =\frac{s_{K}}{n+g_{k}+d}
\end{aligned}
$$

We can rewrite (9) by dividing both sides with $A_{t}$ to arrive at:

$$
\begin{aligned}
& \frac{\dot{A}_{t}}{A_{t}}=\frac{\delta \cdot H_{A_{t}}^{\lambda} \cdot\left[\left(\frac{A_{t}^{*}}{A_{t}}\right)^{1-S} \cdot A_{t}\right]^{\varnothing}}{A_{t}} \\
& g_{A_{t}}=\frac{\delta \cdot H_{A_{t}}^{\lambda} \cdot A_{t}^{* \varnothing(1-S)}}{A_{t}^{\phi(1-S)} \cdot A_{t}^{1-\phi}} \\
& g_{A_{t}}=\frac{\delta \cdot H_{A_{t}}^{\lambda} \cdot A_{t}^{* \varnothing(1-S)}}{A_{t}{ }^{(1-S . \varnothing)}} \\
& A_{t}^{(1-\mu \phi)}=\frac{\delta \cdot H_{A_{t}}^{\lambda} \cdot A_{t}^{* \Phi(1-S)}}{g_{A_{t}}} \\
& A_{t}=\left[\frac{\delta \cdot H_{A_{t}}^{\lambda} \cdot A_{t}^{*} \phi(1-S)}{g_{A_{t}}}\right]^{\frac{1}{(1-S . \phi)}} \\
& A_{t}=\left(\frac{\delta}{g_{A_{t}}}\right)^{\frac{1}{(1-S \cdot \phi)}} \cdot H_{A_{t}}^{\frac{\lambda}{(1-S . \phi)}} \cdot A_{t}^{*} \frac{\phi(1-S)}{(1-S . \phi)}
\end{aligned}
$$


If we notice equation (11), we can find out that:

$$
A_{t}^{\frac{\sigma}{1-\alpha}}=\left[\left(\frac{\delta}{g_{A_{t}}}\right)^{\frac{1}{(1-S . \phi)}} \cdot H_{A_{t}}^{\frac{\lambda}{(1-S . \phi)}} \cdot A_{t}^{*} \frac{\phi(1-S)}{(1-S \cdot \phi)}\right]^{\frac{\sigma}{1-\alpha}}
$$

If we let: $\frac{\sigma}{1-\alpha} \cdot \frac{\lambda}{(1-S \cdot \phi)}=\gamma$, and because $\sigma$ is hard to detect or measure according to Jones (2002), we then normalize to arrive at: $\sigma=1-\alpha$, then $\gamma=\frac{\lambda}{(1-S . \phi)}$.

$$
A_{t}=\left(\frac{\delta}{g_{A_{t}}}\right)^{\frac{\gamma}{\lambda}} \cdot H_{A_{t}}^{\gamma} \cdot A_{t}^{* \frac{\phi \gamma(1-S)}{\lambda}}
$$

We insert equation (11.c) and (11.d) to equation (11) to arrive at:

$$
y_{t}=\left(\frac{s_{K}}{n+g_{k}+d}\right)^{\frac{\alpha}{1-\alpha}} \cdot l_{Y_{t}} \cdot h_{t} \cdot\left(\frac{\delta}{g_{A_{t}}}\right)^{\frac{\gamma}{\lambda}} \cdot H_{A_{t}}^{\gamma} \cdot A_{t}^{* \frac{\phi \gamma(1-S)}{\lambda}}
$$

Next, we can manipulate equation (12) to obtain growth rate at balanced growth path, namely:

$$
\begin{aligned}
& \log y_{t}=\log \left[\left(\frac{s_{K}}{n+g_{k}+d}\right)^{\frac{\alpha}{1-\alpha}}\right]+\log l_{Y_{t}}+\log h_{t}+\log \left(\frac{\delta}{g_{A_{t}}}\right)^{\frac{\gamma}{\lambda}}+\log H_{A_{t}} \gamma+\log A_{t}^{* \frac{\phi \gamma(1-S)}{\lambda}} \\
& \log y_{t}=\frac{\alpha}{1-\alpha} \cdot \log \left(\frac{s_{K}}{n+g_{k}+d}\right)+\log l_{Y_{t}}+\log h_{t}+\frac{\gamma}{\lambda} \cdot \log \left(\frac{\delta}{g_{A_{t}}}\right)+\gamma \cdot \log H_{A_{t}}+\frac{\phi \gamma(1-S)}{\lambda} \log A_{t}^{*}
\end{aligned}
$$

Since we already know that at balanced growth path, all variables grow at constant rate therefore allocation variables such $s_{K}, l_{Y_{t}}, l_{h t}, l_{A_{t}}$ will remain constant.

We can then derive with respect to time to get:

$$
\begin{aligned}
& \frac{\mathrm{d} \log y_{t}}{d t}=\frac{\alpha}{1-\alpha} \cdot \frac{d \log \left(\frac{s_{K}}{n+g_{k}+d}\right)}{d t}+\frac{d \log l_{Y_{t}}}{d t}+\frac{d \log h_{t}}{d t}+\frac{\gamma}{\lambda} \cdot \frac{d \log \left(\frac{\delta}{g_{A}}\right)}{d t}+\gamma \cdot \frac{d \log h_{t}}{d t}+ \\
& \gamma \cdot \frac{d \log L_{A_{t}}}{d t}+\frac{\emptyset \gamma(1-S)}{\lambda} \cdot \frac{d \log A_{t}^{*}}{d t} \\
& \frac{\dot{y}}{y}=g_{y}=\gamma \cdot \frac{\dot{L}}{L}+\frac{\emptyset \gamma(1-S)}{\lambda} \cdot \frac{\dot{A}^{*}}{A^{*}}=\gamma \cdot n+\frac{\emptyset \gamma(1-S)}{\lambda} \cdot g_{A_{t}^{*}} \\
& g_{y}=\gamma \cdot n+\frac{\emptyset \gamma(1-S)}{\lambda} \cdot g_{A_{t}^{*}}
\end{aligned}
$$

If we take a closer look at equation (12.a), then there are two components that influence $g y$, namely: 1) y.n dan 2) $\frac{\phi \gamma(1-S)}{\lambda} \cdot g_{A_{t}^{*}} \cdot \gamma \cdot n$ expresses duplication in research or effectiveness in research because $\gamma \cdot n=\frac{\lambda}{(1-S . \phi)} \cdot n_{\text {where }} \lambda$ measures level of duplication in research. $\lambda>0$ shows how many individuals who conduct research in the same area or problems. The more individuals working the same research, then we say it is less effective because other resources can be directed to other different research or problem areas.

Kortum (1997), and Lambson \& Phillips (2007) both state that whenever there is an increase in duplication rate then diminishing in return comes into play. $\frac{\not \gamma(1-S)}{\lambda} \cdot g_{A_{t}^{*}}$ measures 
the impact of past research on current research that is heavily influenced by technological progress in advanced countries, $g_{A_{t} \text {. }}^{*}$

If $\gamma \cdot n$ and $\frac{\phi \gamma(1-S)}{\lambda} \cdot g_{A_{t}^{*}}$ are both combined then those parameters show a level of productivity in research. Let us say $\frac{\emptyset \gamma(1-S)}{\lambda} \cdot g_{A_{t}^{*}}=\tau$, for simplicity, then long-run output growth can be rewritten as $g_{y}=\gamma \cdot n+\tau$ or we can simply say that long-run output growth is influenced by the productivity of research.

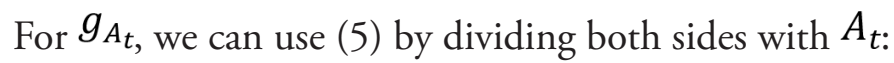

$$
\begin{gathered}
\frac{\dot{A}_{t}}{A_{t}}=\frac{\delta \cdot H_{A_{t}}^{\lambda}\left[\left(\frac{A_{t}^{*}}{A_{t}}\right)^{1-S} \cdot A_{t}\right]^{\varnothing}}{A_{t}} \\
g_{A_{t}}=\frac{\delta \cdot H_{A_{t}}^{\lambda} \cdot A_{t}^{* \varnothing(1-S)}}{A_{t}{ }^{(1-S . \varnothing)}}
\end{gathered}
$$

Next, we take log on both sides and then derive with respect to time:

$$
\begin{aligned}
& \log g_{A_{t}}=\log \delta+\lambda \cdot \log H_{A_{t}}+\emptyset(1-S) \cdot \log A_{t}^{*}-(1-S \cdot \phi) \cdot \log A_{t} \\
& \frac{d \log g_{A_{t}}}{d t}=\frac{d \log \delta}{d t}+\lambda \cdot \frac{d \log \left(h_{t} \cdot L_{A_{t}}\right)}{d t}+\emptyset(1-S) \cdot \frac{d \log A_{t}^{*}}{d t}-(1-S \cdot \phi) \cdot \frac{d \log A_{t}}{d t} \\
& \quad(1-S \cdot \phi) \cdot \frac{\dot{A}_{t}}{A_{t}}=\lambda \cdot \frac{\dot{L}}{L} \\
& g_{A_{t}}=\frac{\lambda \cdot n+\emptyset(1-S) \cdot g_{A_{t}^{*}}}{(1-S . \phi)}
\end{aligned}
$$

Equation (12.a) is the same as equation (12.b) therefore:

$g_{y}=g_{A_{t}}$

because $n=\frac{\sigma}{1-\alpha} \cdot \frac{\lambda}{(1-S . \phi)} \cdot n$, we can rewrite:

$g_{y}=\frac{\sigma}{1-\alpha} \cdot g_{A_{t}}$

$g_{y}=\frac{\sigma}{1-\alpha} \cdot \frac{\lambda}{(1-S . \phi)} \cdot n$

Next is to manipulate equation (11) to arrive at equation (13):

$y_{t}=\left(\frac{K_{t}}{Y_{t}}\right)^{\frac{\alpha}{1-\alpha}} \cdot l_{Y_{t}} \cdot h_{t} \cdot A_{t}^{\frac{\sigma}{1-\alpha}}$

Take logs on both sides:

$\log y_{t}=\frac{\alpha}{1-\alpha} \cdot \log \left(\frac{K_{t}}{Y_{t}}\right)+\log l_{Y_{t}}+\log h_{t}+\frac{\sigma}{1-\alpha} \cdot \log A_{t}$ 
Then derive with respect to time:

$$
\begin{aligned}
& \frac{\mathrm{d} \log y_{t}}{d t}=\frac{\alpha}{1-\alpha} \cdot \frac{\mathrm{d} \log \left(\frac{K_{t}}{Y_{t}}\right)}{d t}+\frac{d \log l_{Y_{t}}}{d t}+\frac{d \log h_{t}}{d t}+\frac{\sigma}{1-\alpha} \cdot \frac{d \log A_{t}}{d t} \\
& \frac{\mathrm{d} \log y_{t}}{d t}=\frac{\alpha}{1-\alpha} \cdot\left(\frac{\mathrm{d} \log K_{t}}{d t}-\frac{\mathrm{d} \log Y_{t}}{d t}\right)+\frac{d \log l_{Y_{t}}}{d t}+\frac{d \log h_{t}}{d t}+\frac{\sigma}{1-\alpha} \cdot \frac{d \log A_{t}}{d t} \\
& \frac{\mathrm{d} \log y_{t}}{d y_{t}} \cdot \frac{d y_{t}}{d t}=\frac{\alpha}{1-\alpha} \cdot \frac{\mathrm{d} \log K_{t}}{d K_{t}} \cdot \frac{d K_{t}}{d t}-\frac{\alpha}{1-\alpha} \cdot \frac{\mathrm{d} \log Y_{t}}{d Y_{t}} \cdot \frac{d Y_{t}}{d t}+\frac{\mathrm{d} \log l_{Y_{t}}}{d l_{Y_{t}}} \cdot \frac{d l_{Y_{t}}}{d t}+\frac{\mathrm{d} \log h_{t}}{d h_{t}} \cdot \frac{d h_{t}}{d t}+ \\
& \frac{\dot{y}_{t}}{y_{t}}=\frac{\alpha}{1-\alpha} \cdot \frac{\mathrm{d} \log A_{t}}{d A_{t}} \cdot \frac{d A_{t}}{d t} \cdot\left(\frac{\dot{K_{t}}}{K_{t}}-\frac{\dot{Y_{t}}}{Y_{t}}\right)+\frac{l_{Y_{t}}}{l_{Y_{t}}}+\frac{\dot{h_{t}}}{h_{t}}+\frac{\sigma}{1-\alpha} \cdot \frac{\dot{A_{t}}}{A_{t}} \\
& g_{y_{t}}=\frac{\alpha}{1-\alpha} \cdot\left(g_{K_{t}}-g_{Y_{t}}\right)+g_{h_{t}}+g_{l_{Y_{t}}}+\frac{\sigma}{1-\alpha} \cdot g_{A_{t}}
\end{aligned}
$$

Add and subtract simultaneously right side of equation (13.c) with " $\gamma \cdot n+\frac{\phi \gamma(1-S)}{\lambda} \cdot g_{A_{t}^{* \prime}}$ to arrive at:

$$
\begin{aligned}
& g_{y_{t}}=\frac{\alpha}{1-\alpha} \cdot\left(g_{K_{t}}-g_{Y_{t}}\right)+g_{h_{t}}+g_{l_{Y_{t}}}+\frac{\sigma}{1-\alpha} \cdot\left(g_{A_{t}}-\gamma \cdot n+\frac{\emptyset \gamma(1-S)}{\lambda} \cdot g_{A_{t}^{*}}\right)+ \\
& \left(\gamma \cdot n+\frac{\emptyset \gamma(1-S)}{\lambda} \cdot g_{A_{t}^{*}}\right)
\end{aligned}
$$

Equation (14) explicitly states that the growth rate of $Y_{t}\left(g_{y_{t}}\right)$ is driven by the growth rate of the following: capital-output ratio, human capital, and share of labor in goods, multifactor productivity in developed countries. The main difference between Jones (2002) and our modified version lies in the parameters, namely $\tau=\frac{\emptyset \gamma(1-S)}{\lambda} \cdot g_{A_{t}^{*}}$. For a more detailed comparison, refer to the table below. This parameter, $\tau$, is made of other parameters, $\phi, \gamma, \lambda, S$. The first three parameters are the same as that of Jones (2002). The parameter specific to a country is inserted to a new model through the parameter, $S$. This new parameter adds flexibility and power to the new model as we can now analyze different countries with respect to their specific characteristics. Table 1 shows a comparison between Jones Model and the modified version.

When steady state is reached, according to Jones (2002), the growth of output eventually is defined by the parameters $\gamma$ and $n$, which is the parameter of ideas function and the parameter of population growth. It is the number of population growth that devote their time and effort to knowledge and technology that matter. But in the new modified model, those are not the only parameters that define growth. In the modified model, per capita output growth in the long term is influenced by the growth factor of the exogenous population, $n$, and institutional index, $S$, and $\phi$, i.e: 


$$
g_{y_{t}}=\frac{\lambda \cdot n+\emptyset(1-S) \cdot g_{A_{t}^{*}}}{(1-S \cdot \phi)}
$$

Where $1-S$ is an inhibiting factor in economic growth. $S$ is a characteristic factor of a country. By inserting the $S$ parameter, we can analyze a particular country different from the United States that is the reference country in Jones Model. The factors such as rate of duplication in research $(\lambda)$, the ability of past research to affect current research $(\phi)$, and the level of institutional readiness in fostering knowledge and technology $(S)$ also play important roles.

Growth will be generated endogenously through R \& D (Jones, 1995a). Bayarçelik \& Taşel (2012), Blanco et al., (2015), Bozkurt (2015), Freimane \& Bālina (2016), and SokolovMladenović et al., (2016) also shows that the R \& D expenditure will cause an increase of real GDP growth. Khan (2015) concludes that research and development play a significant role in economic growth.

Pece et al., (2015) using proxies of innovation with the number of patents, the number of trademarks, and $\mathrm{R} \& \mathrm{D}$ expenditures. The results provided evidence of a positive relationship between economic growth and innovation. A different result is found by Sylwester (2001), which there no strong association between R\&D and economic growth in 20 OECD countries, but there is a positive association in G7 countries. The effectiveness of an innovation policy that attempts to enhance productivity only based on increasing $R \& D$ intensity (Pessoa, 2010). Çalışkan (2015) states that the quality of growth rates is as much important as their size.

Table 1. Comparison Between Model Jones and The Modified Version

\begin{tabular}{|c|c|c|}
\hline & Jones (2002) & Modified Jones (2002) \\
\hline Production function & $Y_{t}=A_{t}^{\sigma} \cdot K_{t}^{\alpha} \cdot H_{Y_{t}}^{1-\alpha}$ & $Y_{t}=A_{t}^{\sigma} \cdot K_{t}^{\alpha} \cdot H_{Y_{t}}^{1-\alpha}$ \\
\hline $\begin{array}{l}\text { Physical capital } \\
\text { Accumulation } \\
\text { function }\end{array}$ & $\dot{K}_{t}=s_{K_{t}} \cdot Y_{t}-d \cdot K_{t}, K_{0}>0$ & $\dot{K}_{t}=s_{K_{t}} \cdot Y_{t}-d \cdot K_{t}, K_{0}>0$ \\
\hline $\begin{array}{l}\text { Aggregate human } \\
\text { capital function }\end{array}$ & $H_{Y_{t}}=h_{t} \cdot L_{Y_{t}}$ & $H_{Y_{t}}=h_{t} \cdot L_{Y_{t}}$ \\
\hline $\begin{array}{l}\text { Human capital per } \\
\text { person }\end{array}$ & $h_{t}=e^{\psi \cdot l_{h t}}$ & $h_{t}=e^{\psi \cdot l_{h t}}$ \\
\hline $\begin{array}{l}\text { Knowledge } \\
\text { accumulation } \\
\text { function }\end{array}$ & $\dot{A}_{t}=\delta \cdot H_{A_{t}}^{\lambda} \cdot A_{t}^{\phi}$ & $\dot{A}_{t}=\delta \cdot H_{A_{t}}^{\lambda}\left[\left(\frac{A_{t}^{*}}{A_{t}}\right)^{1-S} \cdot A_{t}\right]^{\varnothing}$ \\
\hline $\begin{array}{l}\text { Aggregate human } \\
\text { capital function }\end{array}$ & $H_{A_{t}}=\sum_{i=1}^{M} h_{i t}^{\theta} \cdot L_{A_{i t}}$ & $H_{A_{t}}=\sum_{i=1}^{M} h_{i t}^{\theta} \cdot L_{A_{i t}}$ \\
\hline $\begin{array}{l}\text { Population growth } \\
\text { function }\end{array}$ & $N_{t}=N_{0} \cdot e^{n t}$ & $N_{t}=N_{0} \cdot e^{n t}$ \\
\hline Constraints & $L_{A_{t}}+L_{Y_{t}}=L_{t}=\left(1-l_{h t}\right) \cdot N_{t}$ & $L_{A_{t}}+L_{Y_{t}}=L_{t}=\left(1-l_{h t}\right) \cdot N_{t}$ \\
\hline $\begin{array}{l}\text { Initial growth } \\
\text { accounting function }\end{array}$ & $y_{t}=\left(\frac{K_{t}}{Y_{t}}\right)^{\frac{\alpha}{1-\alpha}} \cdot l_{Y_{t}} \cdot h_{t} \cdot A_{t}^{\frac{\sigma}{1-\alpha}}$ & $y_{t}=\left(\frac{K_{t}}{Y_{t}}\right)^{\frac{\alpha}{1-\alpha}} \cdot l_{Y_{t}} \cdot h_{t} \cdot A_{t}^{\frac{\sigma}{1-\alpha}}$ \\
\hline
\end{tabular}




\begin{tabular}{|c|c|c|}
\hline & Jones (2002) & Modified Jones (2002) \\
\hline \multirow{4}{*}{$\begin{array}{l}\text { Multifactor } \\
\text { Productivity }\end{array}$} & $\sigma \quad \lambda$ & $\lambda=\gamma$ \\
\hline & $\overline{1-\alpha} \cdot \overline{(1-\phi)}=\gamma$ & $\overline{1-\alpha} \cdot \overline{(1-S . \phi)}=\gamma$ \\
\hline & & $\tau=\frac{\emptyset \gamma(1-S)}{\lambda} \cdot g_{A_{t}^{*}}$ \\
\hline & $\begin{array}{l}y_{t}= \\
\left(\frac{s_{K}}{n+g_{k}+d}\right)^{\frac{\alpha}{1-\alpha}} \cdot l_{Y_{t}} \cdot h_{t} \cdot\left(\frac{\delta}{g_{A}}\right)^{\frac{\gamma}{\lambda}} \cdot H_{A_{t}}{ }^{* \gamma}\end{array}$ & $y_{t}=\left(\frac{s_{K}}{n+g_{k}+d}\right)^{\frac{\alpha}{1-\alpha}} \cdot l_{Y_{t}} \cdot h_{t} \cdot\left(\frac{\delta}{g_{A_{t}}}\right)^{\frac{\gamma}{\lambda}} \cdot H_{A_{t}}^{\gamma} \cdot A_{t}^{\frac{\varphi \gamma(1-S)}{\lambda}}$ \\
\hline \multirow[t]{4}{*}{$\begin{array}{l}\text { Growth function at } \\
\text { steady-state }\end{array}$} & $g_{y}=\gamma \cdot n$ & $g_{y}=\gamma \cdot n+\frac{\emptyset \gamma(1-S)}{\lambda} \cdot g_{A_{t}^{*}}$ \\
\hline & $g_{A_{t}}=\frac{\lambda \cdot n}{(1-\phi)}$ & $g_{v}=\gamma \cdot n+\tau$ \\
\hline & & $g_{A_{t}}=\frac{\lambda . n}{1-S . \phi}+\frac{\emptyset(1-S) \cdot g_{A_{t}^{*}}}{(1-S . \phi)}$ \\
\hline & & $g_{A_{t}}=\frac{\lambda \cdot n+\emptyset(1-S) \cdot g_{A_{t}^{*}}}{(1-S \cdot \phi)}$ \\
\hline $\begin{array}{l}\text { Growth accounting } \\
\text { function }\end{array}$ & $\begin{array}{l}g_{y_{t}}=\frac{\alpha}{1-\alpha} \cdot\left(g_{K_{t}}-g_{Y_{t}}\right)+g_{l_{Y_{t}}}+ \\
g_{h_{t}}+\frac{\sigma}{1-\alpha} \cdot\left(g_{A_{t}}-\gamma \cdot n\right)+\gamma \cdot n\end{array}$ & $\begin{array}{l}g_{y_{t}}=\frac{\alpha}{1-\alpha} \cdot\left(g_{K_{t}}-g_{Y_{t}}\right)+g_{h_{t}}+g_{l_{Y_{t}}}+ \\
\frac{\sigma}{1-\alpha} \cdot\left(g_{A_{t}}-\gamma \cdot n+\tau\right)+(\gamma \cdot n+\tau)\end{array}$ \\
\hline
\end{tabular}

\section{Conclusion}

Long-term economic growth in Jones' model is influenced by exogenous population growth rates, $\mathrm{n}$. This is what makes Jones Model a semi-endogenous model, namely (i) growth and technological change in the model itself is endogenous but (ii) long-term growth is absolutely explained by the growth of exogenous populations.

The modified equation provides a general form while Jones Model equation serves a more specific case that is for cases in developed countries.

We can use a modified model with greater flexibility in analyzing any countries in the world within Jones Model framework without having to worry about losing its predictive strength. Greater flexibility also means that semi-endogenous growth model is no longer a privilege of developed countries. Advances in technology and knowledge accumulation are not influenced by a variety of things that were not explained in previous semi-endogenous models. In fact, the modified model produces better predictive strength. Better predictive strength means that the new modified semi-endogenous model has better analysis close to reality. This is the ultimate goal at the end of the model building. The new modified model put stress on institutions whereby government and stakeholders of society as a whole should regard the quality of institutions as valuable. 


\section{References}

Acemoglu, D., Aghion, P., \& Violante, G. L. (2001). Deunionization, Technical Change and Inequality. Carnegie-Rochester Conference Series on Public Policy, 55(1), 229-264.

Acemoglu, D., Johnson, S., \& Robinson, J. (2005). Institutions as the Fundamental Cause of Long-Run Growth. In S. N. Durlauf \& P. Aghion (Eds.), Handbook of Economic Growth 1A (pp. 386-472). Holand: North Holand.

Bayarçelik, E. B., \& Taşel, F. (2012). Research and Development: Source of Economic Growth. Procedia - Social and Behavioral Sciences, 58, 744-753. https://doi.org/10.1016/j. sbspro.2012.09.1052

Blanco, L. R., Gu, J., \& Prieger, J. E. (2015). The Impact of Research and Development on Economic Growth and Productivity in the U.S. States. Southern Economic Journal, 82(3), 914-934. https://doi.org/10.1002/soej.12107

Bozkurt, C. (2015). R\&D Expenditures and Economic Growth Relationship in Turkey. International Journal of Economics and Financial Issues, 5(1), 188-198.

Çalışkan, H. K. (2015). Technological Change and Economic Growth. Procedia-Social and Behavioral Sciences, 195(3), 649-654. https://doi.org/10.1016/j.sbspro.2015.06.174

Coe, D. T., \& Helpman, E. (1995). International R \& D Spillovers. European Economic Review, 39, 859-887.

Coe, D. T., Helpman, E., \& Hoffmaister, A. W. (2008). International R\&D Spillovers (IMF Working Paper No. 08/104). Economic Journal. New York: International Monetary Fund.

Freimane, R., \& Bālina, S. (2016). Research and Development Expenditures and Economic Growth in the EU: A Panel Data Analysis. Economics and Business, 29(1), 5-11. https:// doi.org/10.1515/eb-2016-0016

Hall, R. E., \& Jones, C. I. (1999). Why Do Some Countries Produce So Much More Output Per Worker Than Others? The Quarterly Journal of Economics, 114(1), 83-116.

Jones, C. I. (1995a). R \& D Based Models of Economic Growth. Journal of Political Economy, 103, 759-784.

Jones, C. I. (1995b). Time Series Tests of Endogenous Growth Model. Quarterly Journal of Economics, 110, 495-525.

Jones, C. I. (2002). Sources of U.S. Economic Growth in a World of Ideas. American Economic Review, 92, 220-239.

Khan, J. (2015). The Role of Research and Development in Economic Growth: A Review. Journal of Economics Bibliography, 2(3), 128-133.

Kortum, S. (1997). Research, Patenting, and Technological Change. Econometrica, 65, 1389-1419.

Lambson, V. E., \& Phillips, K. (2007). Market Structure and Schumpeterian Growth. Journal of Economic Behavior and Organization, 62(1), 47-62. https://doi.org/10.1016/j. jebo.2004.09.014 
Lucas Jr, R. E. (1988). On the Mechanics of Economic Development. Journal of Monetary Economics, 22(1), 3-42. https://doi.org/10.1016/0304-3932(88)90168-7

Pece, A. M., Simona, O. E. O., \& Salisteanu, F. (2015). Innovation and Economic Growth: An Empirical Analysis for CEE Countries. Procedia Economics and Finance, 26, 461467. https://doi.org/10.1016/S2212-5671(15)00874-6

Pessoa, A. (2010). R\&D and economic growth: How strong is the link? Economics Letters, 107(2), 152-154. https://doi.org/10.1016/j.econlet.2010.01.010

Romer, P. M. (1986). Increasing Returns and Long-Run Growth. Journal of Political Economy, 94(5), 1002-1037.

Sokolov-Mladenović, S., Cvetanović, S., \& Mladenović, I. (2016). R\&D Expenditure and Economic Growth: EU28 Evidence for The Period 2002-2012. Economic Research-Ekonomska Istraživanja, 29(1), 1005-2010. https://doi.org/10.1080/ 1331677X.2016.1211948

Stokey, N. L. (1988). Learning by Doing and the Introduction of New Goods. Journal of Political Economy, 96(4), 701-717.

Sylwester, K. (2001). R \& D and Economic Growth. Knowledge, Technology, and Policy, 13(4), 71-84. https://doi.org/10.1007/BF02693991 